\title{
Missing Calvo? Latin America's love-hate relationship with the Investment Treaty Regime
}

Sa u dades de Calvo? A relação de a mor e ódio d a América Latina com o Regime dos Tratados de Investimento

DOI: https://doi.org/10.22456/2178-8839.113289

Lucas Silva Amorim

Universidade Federal da Paraíba,João Pessoa, Brasil

lucas.amorim1@outlook.com

Mariana Pimenta Oliveira Baccarini Universidade Federal da Paraíba,João Pessoa, Brasil marianabaccarini@gmail.com

Henrique Zeferino de Menezes Universidade Federal da Paraíba, João Pessoa, Brasil hzmenezes@gmail.com

\begin{abstract}
For decades, following the views of the Argentine legal scholar Carlos Calvo, Latin American countries avoided adopting inter national investment treaties. The Calvo doctrine established that disputes between foreign investors and the state should only be settled by national courts, to the exclusion of international jurisdictions. This position eroded as numerous bilateral investment treaties (BITs) were signed during the 1980s and 1990s, exposing the countries of the region to investment lawsuits. Recently, a crisis of the investment treaty regime has been noticed in the region, with the denunciation of both BITs and the ICSID Convention, the non-recognition of arbitral awards, and the negotiation of a new model of investment treaties. The analysis of the historical process of rise and crisis of the investment regime in the region, through the review of documents and data on its effects, demonstrate that countries have taken measures to restrict the possibility of investor-State arbitration. In this sense, the region seems to be experiencing a return to Calvo's doctrine on the need to guarantee countries' decision-making autonomy in strategic policies.
\end{abstract}

Keywords: International Investment Agreements; Investment Treaty Regime; Latin America; Calvo Doctrine; Policy Diffusion;

\section{Resumo}

Por décadas, os países da América Latina evitaram adotar tratados de investimento seguindo os pensamentos do jurista argentino Carlos Calvo. A doutrina Calvo estabelecia que as disputas entre investidores estrangeiros e o Estado deveriam ser resolvidas pelos tribunais nacionais, à exclusão de jurisdições internacionais. Essa posição se erodiu à medida que um número crescente de tratados bilaterais de investimento (BITs) foi assinado nas décadas de 1980 e 1990, expondo os países da região a ações arbitrais de investimento. Recentemente, percebe-se uma crise do regime de investimentos na região, com a denúncia de BITs e da Convenção ICSID, o não reconhecimento de sentenças arbitrais e a negociação de um novo modelo de tratados de investimentos. Da análise do processo histórico de ascensão e crise do regime de investimento, através da análise de documentos e dados sobre os efeitos dos acordos de investimento, pode-se dizer que os países da região têm tomado medidas para restringir a possibilidade de arbitragens Investidor-Estad o. Nesse sentido, estaríamos experimentando um retorno à doutrina de Calvo sobre a necessidade de garantir autonomia decisória sobre políticas públicas estratégicas na região.

Palavras-chave: Acordos Internacionais de Investimento; Regime dos Tratados de Investimento; América Latina, Doutrina Calvo; Difusão de Políticas; 


\section{Introduction}

The investment treaty regime, especially its most tangible aspect, investor -state dispute settlement (ISDS), has recently been a target of criticism not only by the media and policymakers - from both developed and developing countries - but also in specialised literature. ISDS has already been accused of favouring investors to the detriment of the public interest (HAWKINS; HOLDEN, 2016), guaranteeing foreign agents undue influence in the formulation of public policies (PELC, 2017) and even of not fulfilling its mission of increasing foreign direct investmentflows for low and middleincome countries (BERGER et al., 2011, BRADA; DRABEK; IWASAKI, 2020).

Opposition to the investment treaty regime — one of the pillars of the international liberal order-had resulted only in incremental reforms up to the 2000s. More recently, the legitimacy crisis that affects the regime has influenced a series of more extensive changes. The renegotiation of NAFTA sponsored by President Donald Trump severely limited the application of this dispute settlementmechanism. Meanwhile, the inclusion of ISDS in the TTIP (Transatlantic Trade and InvestmentPartnership) ended up becoming one of the deal-breakers for the European Union in its negotiations with the US. The Europeans sought to replace ISDS with a new investment court system that would introduce novelties such as permanent judges and an appeals mechanism if adopted (LAZO, 2015; BALIÑO; CAMPOS, 2020).

Once more, Latin America, like other moments in the history of the investment treaty regime, has a prominent, and somehow, avant-garde role in the global debates on this topic and the search for political and institutional solutions to the contradictions in the functioning of the mechanism under discussion. While reactions in the region are far from homogenous, the most recent developments regarding the investment treatyregime echo the ideas of Carlos Calvo, a 19thcentury Argentine legal scholar and diplomat who seriously criticised the possibility of arbitration disputes between private companies and sovereign countries. He defended that the property of foreigners shouldbe subject to the legal order of its host state. In this sense, it seems that the current criticisms of the regime retake a historic position of Latin American countries, which refused, for decades, to adhere to international agreements that established investor-state arbitration as the main form of dispute resolution.

Based on the chronology proposed by Jandhyala, Henizs and Mansfield (2011), which show the evolution of the investment treaty regime in three phases - adoption, proliferation and stagnation - we argue that this moment of criticism and reform of the regime could be considered a fourth wave which has its origins in Latin America and has spread throughout the developed world. Latin American countries have sought to limit the possibility of investment arbitration by denouncing investment treaties (Ecuador) or the procedural treaties that guarantee their enforcement (Bolivia and Venezuela); formulating a completely new treaty model that excludes ISDS from the array of measures investors have access to (Brazil) or even by taking advantage of a victory in an arbitral lawsuit to implement sweeping changes to the domestic regulatory environment (El Salvador).

The paper proposes a historical analysis, based on specialized literature and the review of documents from arbitration cases and aggregated data on the functioning and effects of investment rules in the region, to assess this change in the position of countries in the region regarding the investment treaty regime. It is questioned whether there is a return, even if figurative, to the principles defended by the countries of the region when the Calvo Doctrine watched over them. To understand this phenomenon better, section $1 \mathrm{will}$ analyse the specificities of the investment treaty regime, bearing in mind that its logic of expansion obeyed different rules than policy coordination in multilateral forums and that this has important theoretical implications. In section 2, we explore the historical context of the 1980s in the region, with a focus on the abandonment of the Calvo Doctrine. In section 3, we seek to understand the reason for the adoption of BITs out of the array of other possible institutional solutions to the crisis. Section 4 further explores the most recent developments in the regime, especially the reactions of Latin American states in response to the breach of expectations with the regime.

Looking at the historical path the investment treaty regime has taken in the region - from the incorporation of the Calvo Doctrine into domesticlaw in the 19th century and the No de Tokio and the New Economic International Order 
in the 1960s and 70s to more recent developments — it seems plausible to conclude that the recent reform efforts do not represent a radical change (i.e. a complete denial of international investment protection rules), but rather are reminiscent of the region's long history with this type of agreement and a return to principles of decision-making autonomy that resume central aspects of Calvo's Doctrine.

\section{Specificities of the investment treaty regime}

The breaking of European colonial empires after World War II lead to a proliferation of decolonisation proces ses. While in the Americas these processes led to virtually all countries becoming independent during the 19th century, colonies existed in Africa and Asia as late as 1975. As the metropolitan jurisdiction became past in recently independent countries, an unanswered question was left hanging in the air: would European companies and investors be left to the "whims" of postcolonial governments?

At the time, the only remedy for foreign investors who felt aggrieved by supposedly illegal or unfair actions of the host country, besides counting on the national legal jurisdiction, was to resort to the diplomatic protection of their home country. This solution caused some problems for both the investors and the home countries. For investors, the lack of autonomy was blatant. They could not initiate the diplomatic protection procedure, only request their home country to do so. Once (and if) the procedure was initiated, all the investors' decision-making power wastransferred to their home state in a process called subrogation. Afterwards, it would be up to the state to direct the case as it desired, even defending its interests to the detriment of its national's. Yet, even for the home state, there were demerits in this system. The political rather than juridical character of diplomatic protection had the potential to damage diplomatic relations with the host country of the investment in the case of a dispute (CHOI, 2007).

The institutional innovation used to circumvent this problem was the establishment of a direct litigation mechanism called investor-state dispute settlement (ISDS). The creation of the new procedure took advantage of a legal framework that was already used to settle disputes between states. Now investors no longer had to depend on the protection of their home country. Within ISDS, individuals and corporations can sue their host states directly before an arbitral tribunal. States signify their consent to international investment arbitration by signing and ratifying international investment agreements (IIAs) ${ }^{1}$ with other states. These agreements establish legally binding standards for the treatment of foreign investors. While investment treaties alone are not able to make arbitral awards effective, the New York Convention on the Recognition and Enforcement of Foreign Arbitral Awards guarantees the worldwide enforcement of investment treatyawards (CHOI, 2007).

In sharp contrast to other international economic regimes - such as the multilateral trade regime, which has the World Trade Organization as its focal point — a decentralized rule-making process is a central characteristic of the investment treatyregime. Negotiation and adoption of procedural rules usually take placein multilateral forums (e.g. the UNCITRAL Model Arbitration Rules and the ICSID Convention and Rules of Procedure). On the other hand, substantive rules, which are the ones that effectively create rights and duties between signatory states and foreign investors, are set up in the investment treaties themselves, a huge part of which is negotiated on a bilateral or regional basis. Together the investment treaties, the procedural rules, and the arbitral awards form what we call throughout this article the investment treaty regime ${ }^{2}$ (BONNITCHA; POULSEN; WAIBEL, 2017).

\footnotetext{
${ }^{1}$ We use the terms international investment agreements and investment treaties as equivalents throughout this paper.

2 While the investment treaty regime does not regulate all aspects of foreign investment, the degree of enforceability with which it is endowed makes it the centre of the more comprehensive investment regime complex. Besides investment treaties, the complex is formed by regimes based on other legal documents such as trade agreements, human rights and environment treaties, codes of conduct, and even investor-state contracts. We purposely avoid the more common term international investment regime, which fails to capture such subtleties in favour of the nomenclature proposed by Bonnitch a, Poulsen and Waibel (2017).
} 
Despite the apparent stability and organicity of the regime as it is, the original plan for the regulation of foreign investment was the establishment of a multilateral regime. The Havana Charter, the founding document of the International Trade Organization that never cameinto force, alreadyprovided for "the adoption of a general agreement or statement of principles regarding the conduct, practices and treatment of foreign investment” (UNITED NATIONS, 1948). After that, other endeavours to adopt multilateral arrangements happened under the auspices of the Organization for Economic Co-operation and Development(OECD).

One of the first attempts, known as the Abs-Shawcross Draft Convention, failed to be adopted in 1967 and the issue only came up again in the 1990s. The original proposal was to include foreign investment protection and liberalization in the WTO Uruguay Round negotiations, but a coalition of developing countries thwarted that endeavour. OECD countries attempted to negotiate a Multilateral Agreement on Investment (MAI), but they failed to reach consensus even among more like-minded partners (CHOMSKY,1998). It is possible to notice the level of disagreement by skimming through a commented version of the draft agreement (OECD, 1998).

The failure of these initiatives had a decisive influence on strategic diffusion and the wording of the BITs that imperfectly replaced the ambitious multilateral agreements proposals. Therefore, the impossibility of concluding any satisfactory multilateral agreementeven among capital-exporting countries was one of the critical motives for extending the networks of bilateral agreements to as many countries as possible (ZENG, 2014). Bilateral and regional negotiations resulted in the signature of 3,318 IIAs between bilateral agreements and other agreements with investment provisions as of March 2019 (UNCTAD, 2019a). The strategy of abandoning multilateral forums in favour of bilateral negotiation also changes the dynamics of rulemaking. The attempt to coordinate the adoption of rules, typical of multilateral negotiations, gives way to a diffusion process, where the adoption of rules depends on the individual objectives of each actor.

For decades, Latin American countries refused to adhere to the international investment regime, making use of the premises and foundations of the Calvo Doctrine. However, from the 1980s and especially the 1990s, there was a huge wave of adhesions to bilateral investment agreements and, consequently, the investor-state dispute settlement mechanism. There are several explanations for the late entry of Latin American countries into the regime-factors associated with the dissemination of these standards as part of the market-oriented reform agenda, as well as strategic calculations by these countries to attract investment. What matters is that, in that period, the Calvo Doctrine was largely abandoned.

\section{Explaining the demand for FDI promoting institutions: abandoning Calvo}

Latin American resistance to granting special jurisdictional rights to foreign investors precedes the investment treaty regime. The Calvo Doctrine made the establishment of foreign investment conditional on the investors agreeing to abandon the possibility of resorting to diplomatic protection from their home country. The phrase diplomatic protection can be misleading, however. When diplomatic means were exhausted, states (especially European powers and the United States) were not afraid to resort to violence in pursuing their citizens' interests. The French interventions in Mexico in the 19 th century - when the European nation used as casus belli the improper treatment of its nationals' property — are a clear example offered by Garcia-Mora (1950) of what became known, quite paradoxically, as gunboat diplomacy.

Latin American legal systems incorporated the Calvo Doctrine by either constitutional and statutory provisions or clauses in contracts signed between the government and foreign investors. Calvo justifies his doctrine on legal principles such as sovereign equality of states, non-intervention and reciprocity in the conduct of international relations, raising awareness to the post-colonial character the settlement of disputes involving property of foreigners had at the time: 
Aside from political motives these interventions have nearly always had as apparent pretexts, injuries to private interests, claims and demands for pecuniary indemnities in behalf of subjects or even foreigners, the protection of whom was for the most part in nowise justified in strict law. According to strict international right, the recovery of debts and the pursuit of private claims does not justify de plano the armed intervention of governments, and, since European states invariably follow this rule in their reciprocal relations, there is no reason why they should not also impose it upon themselves in their relations with nations in the new world (CALVO,1896 apud HERSHEY, 1907, p. 27).

Eventually, the doctrine was expanded and even the adoption of peaceful dispute settlement mechanisms such as investment treaty arbitration became frowned upon. After World War II, direct armed intervention stopped being an open legal question as the Charter of the United Nations (1945) had already outlawed the use of force in most cases. The justification for the continued adherence of Latin American countries to the Calvo Doctrine became one of economic protectionism. While the two world wars kick-started industrialisation in the region, import substitution industrialisa tion became a policy taken up by the states in the 1950s and 1960s. Foreign capital was seen as a competitor to the native industries still in their infancies. Offering special treatment to foreign investors was out of question (BAER, 1972, HIRA, 2007).

The unified opposition of Latin American countries to the adoption of international investment rules - and consequently, ISDS — was manifested in a World Bank meeting in 1964. Out of the 21 countries that opposed the creation of the International Centre for Investment Dispute Settlement 19 were Latin American. This event of collective opposition to the investment treaty regime has become known as El No de Tokio, due to where the meeting took place (BAER, 1972, LAZO, 2015, LOWENFELD, 2009). It is possible to notice the influence of the Calvo Doctrine in the statement of Felix Ruiz, Chilean member of the World Bank's Board of Governors, at the time speaking on behalf of all Latin American countries:

The legal and constitutional systems of all the countries that are members of the Bank offer the foreign investor at present time the same rights and protection as their own nationals; they prohibit confiscation and discrimination and require that any expropriation on justifiable grounds of public interest shall be accompanied by fair compensation fixed, in the final resort, by law courts. The new system that has been suggested would give the foreign investor, by virtue of the fact that he is a foreigner, the right to sue a sovereign state outside its national territory, dispensing with the courts of law. This provision is contrary to the accepted legal principles of our countries and, de facto, would confer a privilege on the foreign investor, placing the nationals of the country concerned in a position of inferiority (ICSID, 2009, p. 606).

In the next decade, developing countries took advantage of their majority in the UN General Assembly to pass economic measures to their benefit. The proposition of resolutions such as the Declaration on the Establishment of a New International Economic Order and the Charter of Economic Rights and Duties of States sought to relativise private property, including the possibility of expropriating/nationalising foreign investments in terms favourable to developing countries - exactly the opposite of the objective of the investment treaty regime. Latin American countries, in the context of the Group of 77 (G77), participated in these movements (UNITED NATIONS, 1974a, 1974b).

Notwithstanding the collective opposition of Latin American countries to the investment treaty regime, the Calvo Doctrine began to erode in the 1980s. Throughout the 1970s and 1980s, Latin American countries only signed 20 IIAs. That number exploded in the 1990s to an impressive 289 according to the United Nations Confer ence on Trade and Development's database on investment treaties (UNCTAD, 2019b). The 1990s was also the decade in which many countries of the region adhered to the ICSID Convention (ICSID, 2020). During the next two decades, 140 more treaties were signed. The evolution of these numbers can be seen in the graph shown in Figure 1.

An analysis of the historical context from the1980s onwards will be required in order to understand this change and Latin American countries' motivation to abandon a three-decade-old strategy of not adopting investment treaties with arbitration provisions. The literature dedicated to understanding the dissemination of international investment agreements emphasises, in particular, three causes behind countries in the region joining the international investment regime late. 
Figure 1 - Number of IIAs signed by Latin American countries ${ }^{3}$

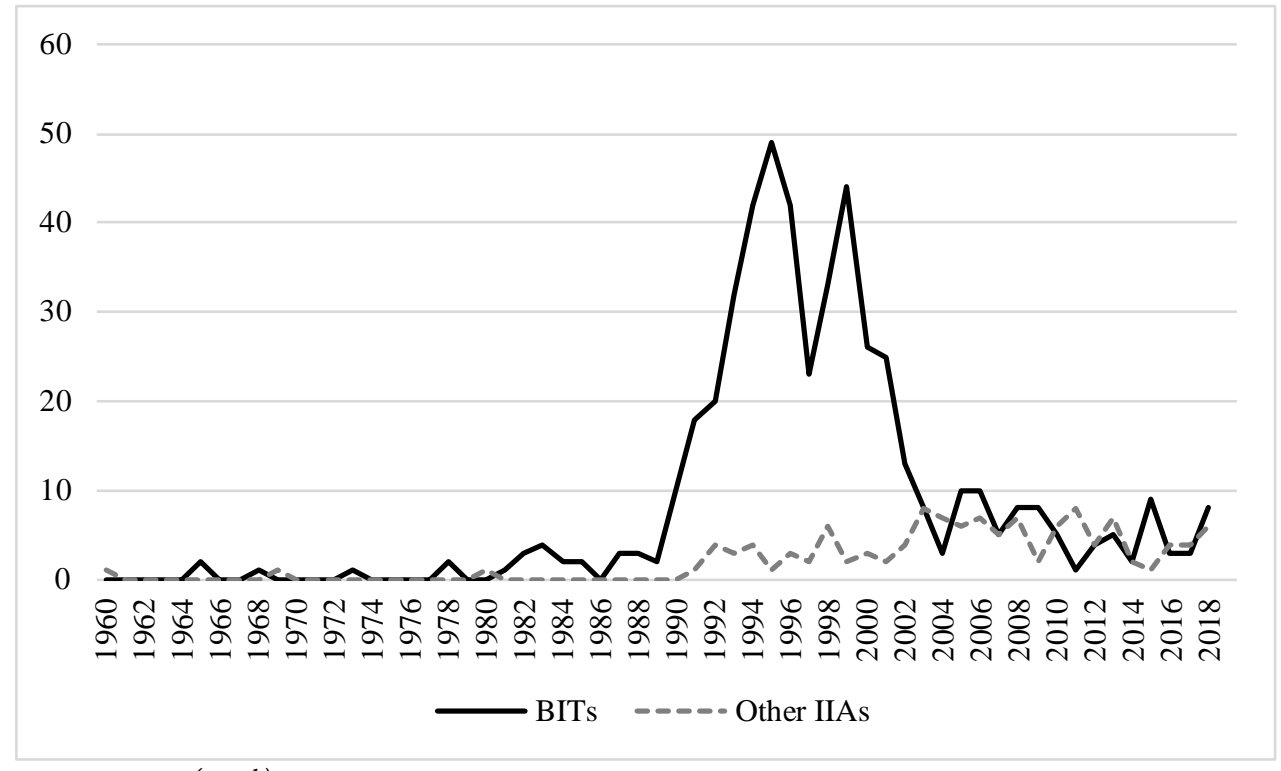

Source: UNCTAD (2019b)

Elkins, Guzman, and Simmons (2006) understand investment treaty diffusion as a rational process that happens in a context of competition for capital. Given the acute balance of payments crises Latin American countries suffered in the 1980s, the attraction of foreign investment would be an important contribution to minimise its macroeconomic effects. This theoretical approach is broadly based on rational choice assumptions that treat the game of FDI as being determined by the incentives (and disincentives) offered by the countries to investors. Briefly, the argument is that the adoption of investment treaties is given as the result of competition among developing countries for the limited amount of FDI available. Signed BITs would divert investment flows before allocated to competitors to the signee. ${ }^{4}$

Jandhyala, Henizs and Mansfield (2011) highlight the role of norm -emulation with the goal of generating both acceptance from developed countries and a feeling of adequacy on the part of the developing countries. The argument defended by the authors is that the investment treaty regime expanded in a process of norm -emulation. The process is described as happening in three waves. The first wave goes from the beginning of the regime to the late 1980s. It was an effort led by developed countries in response to the problem of nationalisation of multinationals in developing countries. This first wave is marked by the signature of IIAs between developed and developing countries (i.e. North -South BITs) revealing clear receivers and suppliers of FDI. The interest of the capital-exporting country would be to protect its investors, while the capital-importing country would be interested in increasing the inflow of FDI.

The second wave has a characteristic that differentiates it from the previous wave; developing countries increasingly signed treaties between themselves (i.e. South-South BITs). The authors call this phenomenon strange BITs (JANDHYALA; HENIZS; MANSFIELD, 2011, p. 1049). The mere existence of these strange BITs defied the previous explanation about investment treaties. After all, whywould countries sign investment agreements with countries that did not have the potential to benefit them with an increased flow of FDI? This argument is especially important in the case under study as this second wave is the period when the bulk of Latin American treaties were signed.

\footnotetext{
3 Statistics refer to the following countries: Argentina, Bolivia, Brazil, Chile, Colombia, Costa Rica, Cuba, Dominican Republic, Ecuador, El Salvador, Guatemala, Haiti, Honduras, Mexico, Nicaragua, Panama, Paraguay, Peru, Uruguay and Venezuela. These are the original nineteen No de Tokio countrie s plus Cuba, not present at the meeting due to its withdrawal from the World Bank in 1960. The option to consider all signed and not only ratified treaties is justified because we wanted to have a measure of the countries' (especially their executive branches) willingness to adopt IIAs, and not of treaties in force.

${ }^{4}$ For a counterargument to the rational competition for capital theory see Poulsen and Aisbett (2013).

${ }^{5}$ Although Elkins, Guzman and Simmons (2006) had already identified this occurrence of strange BITs, they did not explore the concept any further.
} 
The answer provided by the authors was that the second wave did not have the same motivations as the first one. Instead, the signature of these strange treaties was motivated by a logic of fitting in, i.e. even developing states started to perceive BITs as the appropriate form of protecting foreign investors. According to Jandhyala, Henizs and Mansfield (2011, p. 1053) this logic results from the "increased political commitment by governments of both developed and developing countries to economic liberalism and the freer international flow of goods, services and investments”. Keepin mind that this period largely coincides with the rise and consolidation of neoliberalism in many countries of the region, due to conditionalities imposed by creditors and international organizations or to presidents aligned with the neoliberal agenda taking office.

A third argument is based on the information asymmetries associated with the negotiation process and consequently the impossibility of foreseeing the costs associated with the rules of the dispute settlement mechanisms contained in these agreements. Poulsen $(2011,2013)$ follows Weyland's $(2006,2008)$ argument that the diffusion of investment treaties did not arise from a fully rational process, but rather was given in a framework of bounded rationality determined by the distribution of capabilities and power given according to the historical context.

In a context of bounded rationality, decision-makers' options of institutional solutions are limited by two heuristics. First, the heuristic of availability, which is due to the limited time and attention they have to select the policy. These limitations give the most available and memorable policy choices a privileged spot on the agenda. It means that decision-makers may be more inclined to adopt a policy if it has been implementedin a neighbouring country or a country with cultural affinities, for example. Second, the heuristic of representativeness, in which the decision-makers rationality is limited in their assessment of success and failure. An institutional innovation usually diffuses slowly until the first example of apparent success. Even though a single data point is not enough to get to a definitive answer about the effectiveness of the policy, decision-makers take a mental shortcut and are quick to emulate the policy. When time passes and the expectations are not met, the enthusiasm also diminishes and the impetus to adopt the policy is brought down (WEYLAND, 2006).

This seems to be the case with the investment treaty regime. Before the 1990s, the quality of the information about FDI was still relatively poor, curbing the possibility of a thorough analysis of the effectiveness of BITs as a tool to promote foreign direct investment. While it was possible to conduct research through other methods (the author retrospectively suggests surveys with investors), the heuristic of availability may have led decision-makers to ignore this possibility in favour of the anecdotal evidence available to them at the time (POULSEN, 2013).

Three elements in the 1980s' Latin America may have increased the possibility of misinterpretation due to the heuristic of availability. In the first place, the very context of budget crisis coupled with the idea that FDI was a good option to deal with economic problems faced in the period may have influenced decision -makers to overestimate BITs' potential to promote an increase in the FDI inflow. According to Poulsen (2013, p. 5) "governments desperately seeking foreign investment should be particularly easily swayed that investment treaties help attractforeign capital”.

Second, the absence of (publicly known) investment treaty arbitration cases may have potentialized the idea that investment treaties were harmless. According to UNCTAD's (2019c) database on investment dispute settlement, the first case involving a Latin American country, FEDAXv. Venezuela, only happened in 1996, just one year after the period in which the majority of new treaties were signed.

Thirdly, the 1980 s was a period in which capital-exporting countries and international organisations began to campaign or promote investment treaties as an adequate policy in dealing with foreign investment. This amplified the possibilities of getting BITs with developed countries and may have put investment treaties at the top of Latin American decision-makers' minds when the crisis hit (BONNITCHA; POULSEN; WAIBEL, 2017, p. 19).

The three different analyses, groundedin distinct theoretical perspectives on the diffusion and transfer of norms and policies, are not contradictory and apparently reinforce each other in explaining such a profound change. In general 
terms, changes in the international political and economic context during the 1980s and 1990s, associated with regime changes in some countries, as well as government alternation and the emergency of a new national economic agenda led countries in the region to adhere to the international investment regime.

In the next section, we further elaborate on a fourth wave in the investment treaty regime in Latin America. Efforts lead by some countries limit the possibility of ISDS litigation and, tentatively, mark a return of some form to the Calvo Doctrine. The underestimated costs and lack of evidence of real benefits of investment treaties left Latin American countries feeling cheated.

\section{The Great Disappointment: legitimacy crisis and a return to Calvo?}

The investment treaty regime was created by capital-exporting countries and therefore reflects their interests. However, the heterogeneity of their positions on how it should be shaped lead to the failure of the earlier attempts at creating a multilateral investment regime. Even though, the draft texts that came out of these meetings has an impact on the provisions found in the myriad BITs and other IIAs signed since the beginning of the regime in the 1960s. The failure of the multilateral negotiations and the use of its content for the negotiation with developing countries explain how a regime that propagates mainly through bilateral negotiations keeps a sense of coherence (ZENG, 2014).

Although the construction of an international regime with a dispute settlement mechanism based on arbitration has been a demand from developed countries, they are not immune to such an instrument. Capital-exporting countries were not prepared to be the target of arbitral suits. When the 1998 NAFTA arbitral case Loewen $v$. United States came out, it was a turning point for the United States. After the repercussion these cases had in the media and civil society organisations, efforts were made tolimit the interpretative space arbitrators had in relation to the treaty clauses through binding interpretations issued by the NAFTA Free Trade Commission. This prudent, restrained reaction sought to fix that specific issue with no drastic changes to the agreement.

In Latin America, the threat this represented for the states also only became clear when the first cases of investment arbitration were publicised. Early caseslike the 1996 FEDAX $v$. Venezuela definitely had an impact on the image investment treaties had in the region. This first batch of ISDS cases is what marks what Jandhyala, Henizs and Mansfield (2011) call the third wave in the investment treaty regime, a period of reflection in which countries were more deliberate in their choice to sign or not sign new treaties. This is shown in the graph in Figure 2 by the sharp decline in the number of treaties signed after 1996, the year of the first Latin America ISDS case, and the stabilisation in the number of signatures in a lower threshold from the 2000 s onward up to 2007. 


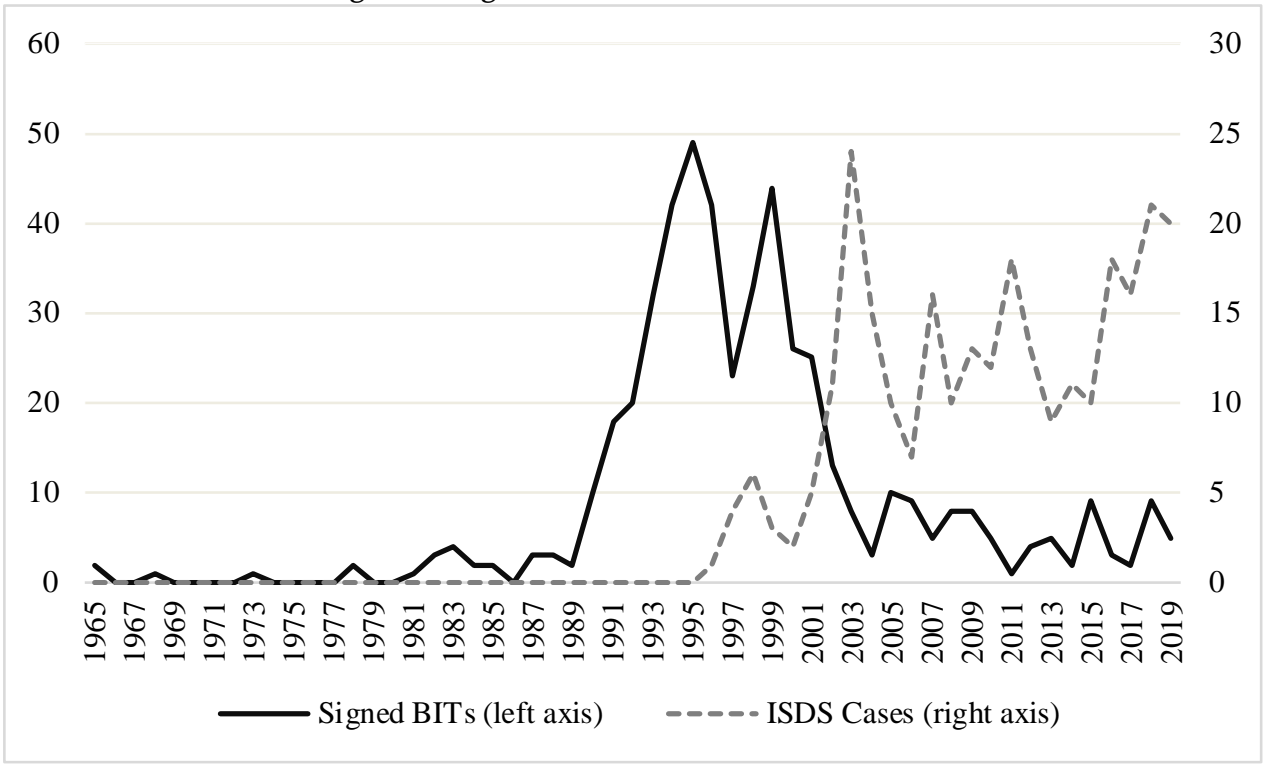

Source: UNCTAD $(2019 a, 2019 b)$

More recent cases, such as Oxy v Ecuador (2007), Pac Rimv El Salvador (2008), Chevron v Ecuador (2009), Philip Morrisv Uruguay (2010) and the many lawsuits related to public debt against Argentina (the first one being Abaclat and others $v$ Argentina, from 2008) are just a few examples of the many investment treaty lawsuits thatwere initiated even after countries started perceiving IIAs as a risk. Whereas the previous third wave is marked by the reduction of the number of signed treaties, the regime has not sailed through calm waters since then as the flat line of the graph might suggest. More recently, the world has witnessed a series of reactions against the investment treaty regime in the region but also in developed countries (UNCTAD, 2019c).

While it is outside of the scope of this paper to analyse each response individually, these reactions seem to be stronger in Latin America than in the other areas of the globe and even in the developed countries. While the first batch of ISDS cases served as an initial exposure to the "antigen", the second batch of arbitral suits triggered a full -scale “immunological response", due to the institutional memory states kept. Remmer $(2019$, p. 806) adds that this stronger response might not be due to an exaggeration on the part of Latin America, but a justified reaction since the region is disproportionately targeted by ISDS suits:

Nowhere is this [the risks of ISDS] more evident than in the Latin American and Caribbean region, whose states have been disproportionately challenged by investment treaty claims and by comparatively high rates of investor success in dispute arbitration. Not surprisingly, the political reaction against ISDS and investment treaty guarantees has also been unusually vehement in the region, leading a number of countries to eschew, formally denounce, or otherwise defect from the existing system of investor-state dispute arbitration.

As Weyland's (2006) bounded rationality theoretical framework predicted, the initial enthusiasm gave place to disappointment as the costs of joining the regime became clear and the evidence for its advantages are, up to this day, ambiguous (BONNITCHA; POULSEN; WAIBEL, 2017, p. 179). This renewed period of resistance to the investment treaty regime in the 2010s after this second batch of ISDS cases represents a fourth wave in the investment treaty diffusion process. A summary of the frustrated expectations and responses is provided in Table 1. The so-called Bolivarian Republics (Bolivia, Venezuela and Ecuador) seem to be the most visible and radical example of opposition to investment arbitration. While the first two countries have focused their efforts against the most procedural aspect of the regime, having denounced the ICSID convention and initiated a process of renegotiation of their networks of BITs, Ecuador went a step further and denounced many of the international investment tre aties it had previously ratified (COSTA; LUÍS, 2016, BAS, 2018a). 
Table 1- Summary table of the fourth wave in the investment treaty regime

\begin{tabular}{ll|l} 
Expectations & Frustrations & Responses \\
\hline $\begin{array}{l}\text { Capital inflow in the context of a } \\
\text { generalised financial crisis in the } \\
\text { region. }\end{array}$ & $\begin{array}{l}\text { Ambiguous evidence of increased } \\
\text { FDI inflow. }\end{array}$ & $\begin{array}{l}\text { Latin America } \\
\text { Denunciation of both BITs and the } \\
\text { ICSID Convention. } \\
\text { Non-recognition of arbitral awards. } \\
\text { Negotiation of a new model of }\end{array}$ \\
\hline $\begin{array}{l}\text { Market-oriented reforms and } \\
\text { modernization of public } \\
\text { management in a context of crisis }\end{array}$ & $\begin{array}{l}\text { Crisis of the neoliberal model. } \\
\text { Criticism of a wide set of } \\
\text { international rules, including the } \\
\text { investor-state dispute settlement. } \\
\text { Investment treaties written to } \\
\text { benefit capital exporters. }\end{array}$ & $\begin{array}{l}\text { Reformulation of the domestic legal } \\
\text { order to strengthen environmental } \\
\text { provisions. }\end{array}$ \\
\hline $\begin{array}{l}\text { Low economic, social and political } \\
\text { costs in joining the regime. }\end{array}$ & $\begin{array}{l}\text { Region disproportionately affected } \\
\text { by ISDS cases. } \\
\text { Policy space affected by arbitral } \\
\text { awards (Regulatory chill). }\end{array}$ & $\begin{array}{l}\text { Developed Countries } \\
\text { Treaty language clarification. } \\
\text { Appeals mechanism. }\end{array}$ \\
\hline Source: Table elaborated by the authors. & $\begin{array}{l}\text { Trump's NAFTA renegotiation } \\
\text { (exceptional case) }\end{array}$ \\
\hline
\end{tabular}

Although more timid, other countries adopted changes that were based on the limitation of the possibility of ISDS with the intention of increasing its level of autonomy from the regime, in consonance with the Calvo Doctrine. Brazil, always an outlier for never having ratified neither the ICSID Convention nor any of the BITs it signed, created a new model of investment treaty in response to its new role as an important capital exporter. This new treaty model called CFIA (Cooperation and Facilitation Investment Agreements) does not offer the country's consent to investor-state arbitration and substitutes ISDS for a series of state-state dispute settlement procedures that involve consultations, mediation and as a last resort state-state arbitration. El Salvador, on the other hand, took advantage of the victory in an ISDS case against the mining company Pac Rim and made a series of changes in its internal regulatory order with an intention of strengthening environmental protection. While it did not revoke any of the investment treaties it signed, the victory in the ISDS case worked as a catalyst for a series of actions aimed at increasing the autonomy the country has concerning the investment treatyregime (BAS, 2018a).

Reactions in developed countries were, in general, more restrained than in Latin America. The European Union's proposal is more reformist and seeks not to address the root of the problem, granting special jurisdictional rights to investors, but to create an appeals procedure to try to solve the problem of inconsistent decisions by arbitral tribunals that plagues the regime. That is despite the European Parliament's opposition to the inclusion of ISDS in new trade agreements to which the EU is a party taken in light of the recent ISDS cases in Europe such as Vattenfallv Germany (2009) (LAZO, 2015, BAS, 2018b). Under President Obama, the United States had reformulated its model BIT in an effort to answer the most pressing criticisms of the investment regime: inconsistency in language that would give too much interpretative sway to arbitrators, and labour and environmental provisions to attend to domestic constituencies (trade unions and environmentalists). The changes introduced have been described as “modest and incremental” by Stokes and Patel (2012, p. 22) (ANDERSON, 2017).

Besides Australia's ban on ISDS in new treaties, a change that was quickly reversed with the transition from a Labor to a Liberal-led government (KWAN, 2015), the most radical development in the developed countries has been Trump's NAFTA renegotiation. The reforms introduced by the trilateral negotiation have led to the creation of what can be seen as two bilateral investment regimes under the recently ratified United States -Mexico-Canada Agreement (USMCA). Between Canada and the United States, the possibility of arbitration has been completely eliminated, while between 
Mexico and the United States, ISDS is still possible, but under severely restricted conditions (i.e. only in disputes involving certain industries). Investment relations between Canada and Mexico will probably be governed by the more liberal СРTPP, the spiritual successor to Obama's TPP, ${ }^{6}$ which was abandoned by Trump in the first days of his administration (UNITED STATES, 2018). Such a counterintuitive chain of events deserves, however, more careful consideration in another study.

\section{Conclusion}

First, it is important to emphasize the unique characteristics of the investment treaty regime. Unlike other international economic regimes, such as the monetary and trade regimes, the investment regime is not structured within a multilateral organization, but from a wide range of bilateral agreements, which converge itself with the acceptance of similar basic principles, norms, rules, and a critical decision-making procedure, the investor-state arbitration. This raises important theoretical considerations regarding its expansion process, the adherence to and legitimization of its norms and rules. Likewise, the crises and retractions of the regime respond to processes linked to political interests that express themselves unilaterally, but that can happen in a coordinated way or in blocks.

While part of the literature was dedicated to understand the diffusion of investment protection rules in the region based on particular theoretical interpretations, we looked at a "multivariable" explanation which reached a synthesis of the main approaches to capture the nature of the complex historical context that lead to the massive adoption of treaties in the 1990s. Certainly, the competition for capital was a plausible explanation regarding the need to balance the crisis in Latin America countries during the Década Perdida ${ }^{7}$ of the 1980s. Meanwhile, the ideological role of international organisms and governments aligned with neoliberalism is another is another pertinent explanation for the adherence to globally outlined normative standards.

These two mentioned aspects explain why the regime expanded in the past, while the analysis of the concrete effects produced by the adherence to the regime is especially useful to understand why it has been the target of backlash more recently. Understanding the economic pressures and the information asymmetry as a fundamental factors in the negotiation of investment treaties helps to explain the severe underestimation of the risks involved in adhering to the regime especially by developing countries. The expectation of importing capital, attracting investments, and increasing technology transfer to sustain economic growth actually led to a wave of investment litigation. The costs and risks associated with this kind of international litigation, as well as the reduction of the countries political and regulatory autonomy, led to complaints, defections and reforms in the investment treaty regime in the region.

Latin America's behaviour, in the case, seems to follow the idiom "once bitten, twice shy" as the reactions from the governments of the region are more assertive than most of the developed countries' - to the notable exception of the United States, under an exceptionally nationalistic and anti-globalist president. While modest reforms seem (or, at least, seemed in the case of the US) to be enough to appease the anxieties caused by the regime's legitimacy crisis in the developed countries, the Latin Americans' worries were only effectively addressed, in most cases, by the elimination of the (legal or factual) possibility of investor-state arbitration. While we do not in any way perceive this situation as the rebirth from the ashes of the Calvo Doctrine, it is a remarkable historical parallel that mustnot be ignored.

\footnotetext{
${ }^{6}$ Respectively, the Trans-Pacific Partnership and Comprehensive and Progressive Agreement for Trans-Pacific Partnership, the latter includes most of the parties of the former to the exception of the United States.

${ }^{7}$ Lost decade, in Spanish and Portuguese.
} 


\section{References}

ANDERSON, Greg. How did investor-state dispute settlement get a bad rap? Blame it on NAFTA, of course. The World Economy, vol. 40 n. 12, p. 2937-2965,2017. Disponível em: https://doi.org/10.1111/twec.12515. Acesso em: 23 abr. 2021.

BAER, Werner. Import Substitution and Industrialization in Latin America: Experiences and Interpretations. Latin American Research Review, v. 7, n. 1, p. 95-122,1972. Disponível em: https://www.jstor.org/stable/2502457. Acesso em: 23 abr. 2021.

BAS V., Magdalena (2018a). Detrás de la autonomía: América Latina y la solución de controversias inversor -Estado. Densidades, n. 23, p. 11-31. Disponível https://www.researchgate.net/publication/326305589_Detras_de_la_autonomia_America_Latina_y_la_solucion_de_controversias_inv ersor-Estado. Acesso em: 23 abr. 2021.

BAS V., Magdalena (2018b). Régimen de solución de controversias inversor-Estados: jresistencias del modelo relacional en un marco institucional de las relaciones internacionales? Relaciones Internacionales, n. 54/2018, p. 163-178, 2018b. Disponível em: https://doi.org/10.24215/23142766e032. Acesso em: 23 abr. 2021.

BERGER, Axel; BUSSE, Matthias; NUNNENKAMP, Peter; ROY, Martin. More stringent BITs, less ambiguous effects on FDI? Not a bit! Economics Letters, v. 112, n. 3, p.270 -272, 2011. Disponível: https://doi.org/10.1016/j.econlet.2011.05.026. Acesso em: 23 abr. 2021.

BALIÑO, Sofia; CAMPOS, Soledad Lea. The USMCA Is Now In Force. How will it impact North American trade policy? 2020. Disponível em: https:/www.iisd.org/articles/usmca-impact-north-american-trade. Acesso em: 17 set. 2020.

BONNITCHA, Johnatan; POULSEN, Lauge N. Skovgaard; WAIBEL, Michael. The Political Economy of the Investment Treaty Regime. Oxford: Oxford University Press, 2017.

BRADA, Josef C.; DRABEK, Zdenek; IWASAKI, Ichiro. Does Investor Protection Increase Foreign Direct Investment? A Meta-Analysis. Journal of Economic Surveys, 30 set. 2020. Disponível em: https://doi.org/10.1111/joes.12392. Acesso em: 23 abr. 2021.

CALVO, Carlos. Le Droit International Théorique et Pratique. Paris: Arthur Rousseau Éditeur, 1896.

CHOI Won-Mog. The present and future of the investor-State dispute settlement paradigm. Journal of International Economic Law, v. 10, n. 3, p.725-747, 2007. Disponível em: https://dx.doi.org/10.1093/jiel/jgm024. Acesso em: 23 abr. 2021.

CHOMSKY, Noam. Domestic Constituencies. Z Magazine. 1998. Disponível em: https://zcomm.org/zmagazine/domesticconstituencies-by-noam-chomsky/.Acesso em: 26 jul. 2019.

COSTA, José A. F.; LUÍS, Daniel T. Repúblicas bolivarianas e o ICSID: será que o inimigo não é outro? Anuario Mexicano de Derecho Internacional, v. 1, n. 16, p. 189, 2016. Disponível em: https://doi.org/10.22201/iij.24487872e.2016.16.525. Acesso em: 23 de abr. 2021.

ELKINS, Zachary; GUZMAN, Andrew T.; SIMMONS, Beth A. Competing for Capital: The Diffusion of Bilateral Investment Treaties, 19602000. International Organization, v. 60, n. 4, p.811-846, 2006. Disponível em: https://doi.org/10.1017/S0020818306060279. Acesso em: 23 de abr. 2021

GARCIA-MORA, Manuel R. The Calvo Clause in Latin American Constitutions and International Law. Marquette Law Review, v. 33, n. 4, p. 205-219,1950. Disponível:https://scholarship.law.marquette.edu/mulr/vol33/iss4/1. Acesso em:23 de abr. 2021.

HAWKINS, Benjamin; HOLDEN, Chris. A Corporate Veto on Health Policy? Global Constitutionalism and Investor-State Dispute Settlement. Journal of Health Politics, Policy and Law, v. 41, n. 5, p.969-995, 2016. Disponível em: https://dx.doi.org/10.1215\%2F03616878-3632203. Acesso em:23 abr. 2021

HIRA, Anil. Did ISI fail and is neoliberalism the answer for Latin America? Re -assessing common wisdom regarding economic policies in the region. Brazilian Journal of Political Economy, v. 27, n. 3, p.345-356, 2007. Disponível em: https://doi.org/10.1590/S010131572007000300002. Acesso em: 23 abr. 2021.

HERSHEY, Amos S. The Calvo and Drago Doctrines. The American Journal of International Law, v. 1, n. 1, p. 26-45,1907. Disponível: https://doi.org/10.2307/2186283. Acesso em:23 abr. 2021.

ICSID. History of the ICSID Convention: Volume II-1. Washington, D.C.: ICSID Publications, 2009.

ICSID. Database of ICSID Member States. 2020. Disponível em: https://icsid.worldbank.org/en/Pages/about/Database - of-MemberStates.aspx. Acesso em: 27 maio 2020.

JANDHYALA, Srividya; HENISZ, Witold J.; MANSFIELD, Edward D. Three Waves of BITs: The Global Diffusion of Foreign Investment Policy. Journal of Conflict Resolution, v. 55, n. 6, p. 1047-1073, 2011. Disponível em: https://doi.org/10.1177/0022002711414373. Acesso em: Acesso em: 23 abr. 2021

KWAN, Edwina. Australia's conflicting approach to ISDS: where to from here? 2015. Disponível em: https://www.lexology.com/library/detail.aspx?g=a7ebe795-dbc1-4e9c-9530-3b8906fab263. Acesso em: 2 jun. 2020.

LAZO, R. Polanco. The No of Tokyo Revisited: Or How Developed Countries Learned to Start Worrying and Love the Calvo Doctrine. ICSID Review, v. 30, n. 1, p.172-193, 2015. Disponível: https://doi.org/10.1093/icsidreview/siu028. Acesso em:23 abr. 2021. 
LOWENFELD, Andreas F. The ICSID Convention: Origins and Transformation. The Georgia Journal of International and Comparative Law, v. 38, n. 1, p.47-61, 2009. Disponível: https://digitalcommons.law.uga.edu/cgi/viewcontent.cgi?article=1109\&context=gjicl. Acesso em: 23 abr. 2021.

OECD. The Multilateral Agreement on Investment: Draft Consolidated Text. 1998. Disponível em: http://www1.oecd.org/daf/mai/pdf/ng/ng987rle.pdf. Acesso em:29 jul. 2019.

PELC, Krzysztof J. What Explains the Low Success Rate of Investor-State Disputes? International Organization, v. 71, n. 03, p.559-583, 2017. Disponível em: https://doi.org/10.1017/S0020818317000212. Acesso em: 23 abr. 2021.

POULSEN, Lauge N. Skovgaard. Sacrificing Sovereignty by Chance: Investment Treaties, Developing Countries, and Bounded Rationality. PhD Dissertation, London School of Economics and Political Science, United Kingdom. 2011. $393 \mathrm{f}$.

POULSEN, Lauge N. Skovgaard (2013). Bounded Rationality and the Diffusion of Modern Investment Treaties. International Studies Quarterly, v. 58, n. 1, p.1-14, 2013. Disponível em: https://doi.org/10.1111/isqu.12051. Acesso em: 23 abr. 2021.

POULSEN, Lauge N. Skovgaard; AISBETT, Emma (2013). When the Claim Hits: Bilateral Investment Treaties and Bounded Rational Learning. World Politics, v. 65, n. 2, p.273-313, 2013. Disponível em: https://doi.org/10.1017/s0043887113000063. Acesso em: 23 abr. 2021.

REMMER, Karen L. Investment Treaty Arbitration in Latin America. Latin American Research Review, v. 54, n. 4, p. 795-811, 2019. Disponível em: https://larrlasa.org/articles/10.25222/larr.154/. Acesso em: 23 abr. 2021.

STOKES, Mathews; PATEL, Niraj. BIT and beyond: advancing the U.S.-India economic relationship. Washington, D.C.: Center for Strategic and International Studies, 2012.

UNCTAD. Draft Convention on Investments Abroad: Abs-Shawcross Draft Convention. In: International Investment Instruments: a Compendium, Geneva and Nova York, v. 5, n. 1, p. 301-303, 2000. Disponível em: http://unctad.org/en/Docs/dite2vol5_en.pdf. Acesso em: 02 out. 2017.

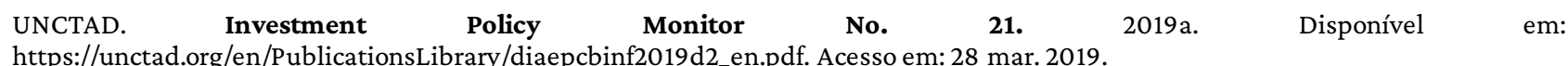

UNCTAD. International Investment Agreements Navigator. 2019b. Disponível em: http://investmentpolicyhub.unctad.org/IIA. Acesso em: 05 set. 2019

UNCTAD. Investment Dispute Settlement Navigator. 2019c. Disponível em: https://investmentpolicy.unctad.org/investmentdispute-settlement. Acesso em: 05 set. 2019

UNITED NATIONS. United Nations Charter. New York, 1945.

UNITED NATIONS. Act of the United Nations Conference on Trade and Employment. Havana, 1948. Disponível em: https://www.wto.org/english/docs_e/legal_e/havana_e.pdf. Acesso em: 07 nov. 2019.

UNITED NATIONS GENERAL ASSEMBLY. Declaration on the Establishment of a New International Economic Order. A/RES/S6/3201. New York, 1974a.

UNITED NATIONS GENERAL ASSEMBLY. Charter of Economic Rights and Duties of States. A/RES/29/3281. New York, 1974b.

UNITED STATES TRADE REPRESENTATIVE. Chapter 14: Investment. In: United States-Mexico-Canada Agreement. 2018. Disponível em: https://ustr.gov/sites/default/files/files/agreements/FTA/USMCA/Text/14 -Investment.pdf. Acesso em: 22 abr. 2020.

WEYLAND, Kurt. Bounded Rationality and Policy Diffusion: Social Sector Reform in Latin America. Princeton: Princeton University Press, 2006.

WEYLAND, Kurt. Toward a new theory of institutional change. World Politics, v. 60, p. 281, 2007. Disponível em: https://heinonline.org/HOL/LandingPage?handle=hein.journals/wpot60\&div=15\&id=\&page=. Acesso em: 23 abr. 2021

ZENG Huaqun. Balance, Sustainable Development, and Integration: Innovative Path for BIT Practice. Journal of International Economic Law, v. 17, n. 2, p.299-332, 1 jun. 2014. Disponível em: http://dx.doi.org/10.1093/jiel/jgu019. Acesso em:23 abr. 2021.

\begin{tabular}{ll}
\hline Authors' Contributor Roles & \\
\hline Lucas Silva Amorim: & Conceptualization; Methodology; Visualization; Formal Analysis; Investigation; Writing (Original Draft Preparation); \\
Mariana Pimenta Oliveira Baccarini: & Conceptualization; Methodology; Validation; Project Administration; Supervision; Writing (Review \& Editing); \\
& Conceptualization; Methodology; Validation; Project Administration; Funding Acquisition; Supervision; Writing (Review \& \\
\hline
\end{tabular}

